\title{
PROBLEMS WITH INNOVATION. THE ANALYSIS OF REGIONAL INNOVATION SYSTEMS IN POLAND
}

\begin{abstract}
The article takes up the issue of evaluation of innovation policy implemented by the Polish authorities since 2000. The unit of the analysis is the regional innovation systems, implemented and funded in accordance with the directives and from EU sources. On the basis of the analysis of secondary data, performed by the method of desk research contained in the report of the Polish Agency for Enterprise Development, rankings of the Organization for Economic Cooperation and Development and the European Union, the author concludes that in Poland, the innovation policy is not effectively implemented. This is mainly due to specific economic and social circumstances, which are different from those assumed, among others, in the Lisbon Strategy. Because in Poland there is no innovation potential, which by assumption should be the proper addressee of innovation policy, the funds placed on stimulating innovation result in the decrease in the quality of research and development activity and the displacement of private funds. Critical evaluation of innovation policy implemented at EU beck and call leads the author to reflect on the question whether at all it is possible for Poland to become innovative economy.
\end{abstract}

Keywords: innovation, innovation policy, regional innovation system.

\section{INTRODUCTION}

Over the last two decades, innovation has been gaining in popularity as one of the most desirable attributes of economies of developed and developing countries. As the result of engagement of international organizations: first, the Organization for Economic Development (hereinafter OECD) since the mid-1990s, also the European Union (hereinafter EU), there has been global diffusion of the idea of innovation as a remedy for the problems of countries that are facing economic recession. The OECD strategy had its scientific legitimization: it was the concept of European tradition of technology studies, more often referred to as innovation studies, initiated in the late 1970s by British economist Ch. Freeman. From this perspective, innovative activity of companies and research centres is perceived as an effective way of increasing economic competitiveness of countries, and as a result, citizens' prosperity. In the late 1990s, as a result of intensive growth of research programmes financed and coordinated by the EU, processes legitimizing the idea of innovation were intensified. One project concerning innovative policy, Targeted Socioeconomic Research, was initiated in 1995 (Lundvall, Borras, 1997).

\footnotetext{
${ }^{1}$ Agnieszka Karpińska, PhD, Department of Sociology of Knowledge and Education, the Institute of Sociology and Cognitive Sciences, University of Bialystok, street Plan NZS 1, 15-420 Bialystok, Poland; e-mail: agnieszka.karpinska@uwb.edu.pl. ORCID: 0000-0002-9316-8413.
} 


\section{ORIGIN OF REGIONAL INNOVATION SYSTEMS}

At the turn of the $21^{\text {st }}$ century, the development of national innovation systems became member states' priority task from the point of view of innovation studies and the strategies of international organizations such as the OECD and the EU. The motivation for that was Finnish success story, mainly illustrated with the Nokia concern. The Lisbon Strategy adopted in 2000 (Czerwińska, 2004) assumed radical economic transformation of the EU, which was expected to defeat the USA and Japan in the innovation competition. The perpetuum mobile of European economic explosion was identified with research carried out in areas of socially useful knowledge. The strategy was equipped with numerous directives, of a more regulatory character than necessary (Okoń-Horodyńska, 2014). The EU policy assumed that all member states would implement the innovation-based model of economic development. Innovations, in turn, were planned with the emphasis on procedural and systemic thinking, marginalizing the very essence of creating innovations and the mechanisms of their diffusion. Thus, the Lisbon Strategy (Okoń-Horodyńska, 2014) included multiple directives which according to economists were exceedingly regulatory. Incessantly since the year 2000, EU policy has been concentrated on the creation of regional innovation systems (hereinafter RISs), which enforce institutionally the collaboration with the private sector and the research and development (hereinafter R\&D) sector through various institutions controlled and coordinated by the state. In accord with the interpretation of innovation studies, a regional innovation system is a system of interactions between actors influencing innovation processes in the region. Its participants are entities representing spheres such as science and education, R\&D, industry, finance, and public authorities. Institutions that belong to an RIS are e.g., universities, science and technology parks, clusters, and first of all, private enterprises. In the early 1990s, the idea of RISs was borrowed by the epistemic community related to the OECD, especially by B.- $\AA$. Lundvall, from the concept of competitive advantage of nations by M.T. Porter. It was B.-A. Lundvall who characterized an RIS as "an interactive process taking place among many different actors. What is emphasized is that companies do not engage in innovative activity in isolation; hence, innovation should be perceived as a group phenomenon" (Malerba, 2004, 249). Because the RIS concept was not designed for areas with low industrialization level, issues concerning places where collaboration does not exist as a result of competition between companies or of different fields of economic activity were marginalized. Nevertheless, attempts to implement the concept are made in many places like that. Nowadays, RISs are the basic structure in EU innovative policy. It is worth pointing out that as part of Framework Programmes (which are the main tool used in the development of EU innovation potential), Programme 7 implemented in the years 2007-2013 involved the total expenditure of 50.5 billion euros, and the budget of the next programme, being implemented in the 2014-2020 period, is estimated to be approx. 80.2 billion euros. Financial support received through the OECD and the EU promoted quick, global diffusion of innovation systems. However, in many countries this tool is an administrative instrument whose aim is to coordinate relations that do not yet exist and are not sure to exist in the future. This can be confirmed by the assessment of Polish innovative policy through desk research, mostly concerning data included in Polish Agency for Enterprise Development reports and OECD or EU rankings. 


\section{POLISH INNOVATION POTENTIAL}

The discussion of this issue should begin with some introductory comments. First, although for more than a decade Poland has been taking part in international comparative studies of innovation potential using the Oslo Manual methodology (OECD, EUROSTAT, 2005) and in source literature, mostly represented by economists, Polish innovation system is classified as a system in the course of transformation, the available empirical data shows that the system is actually in statu nascendi. Indeed, there exist some component institutions of the system, but there are no relationships between them, It seems legitimate to make a thesis that as a result of the need to allocate financial resources from the EU devoted to the development of innovation, Polish government is implementing a kind of innovative policy, but it is much too early to call it a system. Second, it may happen that the category of innovation system will never be relevant in Polish reality. As a result of investing huge financial resources from the EU, the innovation system - designed as a remedy for the decline in production capacity of economies of developed Western European countries has been copied in a country with completely different history and social structure. In other words, Polish national system of innovation is not compatible with the norms of the existing social systems: economic system and cultural (both education and political) system.

Therefore, data concerning Polish innovation potential, showing that in various classifications it is always among the lowest, is not very surprising. In 2015, Poland ranked 24 on the list of 28 countries classified in the European Union Innovation Scoreboard (EUROPEAN COMMISSION, 2015). In the Global Innovation Index 2015 statistics, Poland was number 46 (out of 141), after the Baltic states, the Czech Republic, Bulgaria and Moldova (Dutta, Lanvin, Wunsch-Vincent, 2015). What is more, despite constant increase of financial resources devoted to stimulate the innovative activity of companies and universities, no return of the expenditure is observed. Suffice it to say that in terms of this factor, Poland ranks 93 in the Global Innovation Index 2015. True, in the above-mentioned rankings Polish system of innovation ranks quite high in terms the quality of human capital. The fair proportion of people with higher education is above the EU mean (Waresa, 2015). The high enrolment ratio does not correlate with the other indicators of innovativeness. In 2013, only 3 out of 22 ratios of innovation system analysed for Poland exceeded the OECD median. These were: the number of mobile broadband connection users, the density of Internet network per resident, and patent collaboration: patents shared with inventors from abroad as part of international procedure - the proportion of all applications (OECD, 2013). What is important, in the 2007-2012 period, the number of patents for Polish inventions in the European Patent Office per 1 million of workers grew threefold. But it is still ten times fewer than the EU mean, and much fewer than the mean for Hungary or the Czech Republic (Waresa, 2015). We can also see a decrease of collaboration between developing entities and those that implement innovations, and between the public and private sectors. The R\&D expenditure of the private sector with relation to gross domestic product (hereinafter GDP) is more than 20 times lower than the OECD median (OECD, 2014). So in Poland is observed the phenomenon of unequal innovation potential: disproportions between the enrolment ratio and the other indicators. In countries with higher ranking, this inequality does not occur. Countries with enrolment ratio lower than in Poland, e.g., Slovakia and the Czech Republic, are improving other categories of innovation much more quickly (EUROPEAN COMMISSION, 2012). In this context, the crucial issue is the level of subsidy for R\&D. Although the government aims to increase that expenditure up to $1.45-1.9 \%$ in 2020 , the 
speed is not satisfactory. Notably, even now R\&D expenditure in the Czech Republic and Slovakia is approx. $1.5 \%$. Another disturbing fact is that the source of all previous increase of GDP resources allocated for this purpose has been European funds (Bukowski, Szpor, Śniegocki, 2012).

At the beginning of the $21^{\text {st }}$ century, Poland, which was then facing the problem of high unemployment (about 20\%) and an acute economic crisis, joined the group of countries that participated in the race for building an internationally competitive innovative economy using the European Union jargon. Definitely, it was the funds coming from EU membership that drove Polish decision-makers to engage in the process. But for the need to distribute EU resources, the issue of innovation would probably not be so common now in Polish public domain. As a community that is still making up for civilization backwardness in many areas resulting from system transformation, we have not worked out the conditions favourable for innovation. But the cohesion policy supporting Poland for many years is now ending, and after 2020 the amount of resources devoted to supporting Polish innovation is likely to be greatly reduced. Nowadays, the stress in EU policy is being shifted towards the building of competitiveness instead of cohesion. The view that the community approach to the development of innovations in the EU is only justified if it involves focusing on and supporting the strongest countries, which are likely to win the competition with less innovative countries where resources are cheaper, so far rather unpopular, is currently growing in popularity (PARP, 2013). Hence, the future financial perspectives will probably mean more and more support for the leading European centres instead of assisting other parts of the Union make up for the developmental gap.

\section{REGIONAL SYSTEMS OF INNOVATION IN POLAND}

RISs will mostly be assesses on the basis of the outcome of a nationwide study carried out by Polish Agency for Enterprise Development as part of the programme Review and analysis of regional systems of innovation in provinces of Poland in the context of preparation to implementing the European cohesion policy after 2013 (PARP, 2013). The goal of the project was to find out whether and how much the previous public programmes have promoted the formation and strengthening of RISs. Three methodological approaches were applied in the study: the analysis of available statistical data, interviews with local decisionmakers and representatives of key institutions, and the Delphi method involving a group of experts from each province.

The basic conclusion from the analysis is strong diversification of innovation potential resulting from the fact that innovation indicators are related to the level of economic development expressed as GDP (PARP, 2013). The authors of the report claim that "we cannot find clear relationships between the types of implemented support programmes or activities connected with the formation and development of RIS implementation structures and innovation indicators of the regions" (PARP, 2013). It is not the formation of institutional infrastructure of innovation systems that generates innovation; innovation primarily depends on the level of economic development of the province (Solow, 1957). This conclusion seems very obvious. Still, it does not refer to the regulatory model of implementing innovations in EU countries following a single procedural pattern. That is why, since 2005, all provinces (except the Mazowieckie one) have had detailed regional strategies of innovation development based on bureaucracy included in particular framework programmes and the strategy following the Lisbon one, Europe 2020 (European Commission, 2010). One 
exception is the degree of regional strategies' compliance with the Innovation Union initiative, which the respondents perceive to be very low, especially in terms of access to financing for innovative small and medium-sized enterprises, support for social innovations, and collaboration between the worlds of science and business. Although formally local authorities view regional innovation strategies positively, the vast majority of them know nothing about the degree of accomplishment of the goals of the strategies (PARP, 2013). Unlike local authorities, the authors of the report notice some faults in regional strategies of innovation, very common and yet trivialized by the respondents. These are, first of all, too general goals, e.g. to build knowledge-based economy. A task expressed this way is not quantifiable. In many cases, no deadlines for the completion of activities, no executors or no sources of financing were specified. A number of strategies do not include a system of monitoring or even an indicator of goal achievement. Interestingly, it must be pointed out that the most innovative Mazowieckie Province adopted its regional strategy as the last province in Poland, in 2008 (PARP, 2013).

Despite bureaucratic EU machine connected with producing tons of documents, which E. Okoń-Horodyńska calls the triumph of form over content, talking about innovations may never replace implementing them (Okoń-Horodyńska, 2014). According to the authors of the report, there is no reason to seek any connections between regions' levels of innovation and the quality of strategic documents they apply. Surely, if it was not for framework programmes, there would not be any national - not to mention regional - strategy of innovation. Real pro-innovation activities were largely or even exclusively determined by the process of centralized programming of European funds in Poland. The authors of the report make a conservative observation that this hypothesis would partially explain the abovementioned lack of relations between the convergence of goals of regional strategies of innovation and the level or dynamics of regions' innovation (PARP, 2013). Dynamic analysis of innovation potential proved that in the 2003-2009 period, when European programmes of innovation system development were implemented, there were little or no changes in regions' ranking positions. A small group of leaders strengthened their dominant position, and provinces with low innovation potential did not change their ranks despite the use of European funds. The authors of the report argue that so far local authorities have not managed to build cohesive systems of innovation. "We can only identify individual institutions, documents and activities - expressions of the system functioning - but we should be aware that they do not make a comprehensive system of innovation" (PARP, 2013). The environment of innovative business, i.e. entities such as clusters, science and technology parks and consortiums, is considered to be the weakest link of RISs. Actually, decision-makers find it difficult to evaluate the role of these institutions. They appreciate the very fact that the institutions exist, but they question the effect of their activities. No relationship is observed between provinces' levels of innovation and positive assessment of the role of those institutions. What is important and interesting, decision-makers from Mazowieckie Province - the region with the highest innovation potential - express the most negative opinions on the role of innovative business environment. The vast majority of the respondents perceive the level of transfer of knowledge from science to industry to be very low. Only few respondents were able to provide isolated examples of such collaboration. They do not have any ideas about what local governments could do to activate the potential of the science sector (PARP, 2013). According to experts, "they lack experience, knowledge, and greater reflection on the very phenomenon of innovation, not to mention strategies of action" (PARP, 2013). So decision-makers appreciate the existence of the science sector, but they can see 
that it plays a negligible or even no role in supporting the innovation of companies. In most cases, enterprises themselves do not manifest the wish to collaborate. In a study involving a representative sample of small and medium-sized enterprises carried out in $2010,76 \%$ of the respondents replied to the question of why innovations were not introduced in their company that there was no need to do so (PARP, 2010). According to local authorities, if entrepreneurs did adopt the concept of innovation, they only did so because of applying for EU funds. What is important, the companies usually spend the subsidies on the purchase of machinery and equipment, thus consolidating the imitation model of innovation, so typical of Poland. Therefore, in all the provinces, most projects are not carried out in partnerships (as expected), but individually. The dominant attitude of the system stakeholders is that if a task can be done individually, no collaboration is pursued.

Thus, I have the impression that local authorities, just like entrepreneurs, only participate in the process of building the innovation system as actors using some tools for an obscure purpose connected with an enigmatic idea of innovation. Both groups display an unjustified belief in universal effects of investing in laboratories and equipment. Representatives of public administration and the private sector alike repeatedly spend EU funds allotted for stimulating innovation on investing in institutions (in the case of local authorities) or machinery and equipment (entrepreneurs). Still, the respondents are grossly surprised and disappointed as they see that investment in research infrastructure does not generate collaboration between the worlds of science and business. Entrepreneurs claim that European regulations have an anti- innovation effect, and representatives of universities admit that although EU financial support has allowed great improvement in the quality of infrastructure, in the long run it will cause financial crises of universities, since they have to contract high loans for their contribution to the projects and for the maintenance of infrastructure (Conference of Rectors of Polish Universities, 2013). As a result, universities have no money for research, but the problem is concealed by the specificity of RIS methodology. In many rankings, innovation success is measured with the scale of obtained and spent EU funds, and those rates are obviously good (Okoń-Horodyńska, 2012). Surely, the most desirable model involves the research institution selling a solution that will be implemented by an enterprise that has the necessary production facilities, unavailable for research laboratories. However, in practice the implementation of this process proves to be more complicated than it seems. Entrepreneurs seek quick and profitable commercial solutions, and universities function in a totally different reality and often find it difficult even to estimate the costs of production of the solution they develop. As for companies, they first of all pursue profit, and they are bound to choose the university that offers goods or services that are not only better but also cheaper. Thus, it is hard to build lasting relationships between the private and public sectors, because the former is simply very "moody".

It seems, however, that the core of the matter is another issue, namely, where (and whether) innovation-stimulating research potential can be found in Poland. So far, innovative activity in Poland has mostly taken place out of the academic circle, in branches of international concerns. That is why the internationalization of invention activity - the indicator referring to patents shared with inventors from abroad - is much higher than the OECD median (OECD, 2014). Some studies show that corporations which move part of their R\&D activity abroad are motivated by supply factors (e.g., the quality of research networks) only in the case of highly developed countries, and by demand factors (e.g., the need to adapt products to local markets) in less developed countries that do not have any advantage in the area of innovation (Narula, Guimon, 2010). Thus, companies' innovation investments in 
Poland do not involve R\&D but rather reproduction, adopting already existing solutions. The ratio of export of innovative goods is quite high, yet, although the goods are manufactured in Poland, the technology and know-how for their manufacture come from abroad. R\&D activity of international corporations involves relatively simple solutions or is based on research centres that use local human resources but are poorly connected with the environment. Concerns do not invest in research and implementation centres that could create innovations for global use. Low revenues from the export of national know-how show that Poland is only a producer of technologically advanced goods that are designed elsewhere. Hence, profits from the production of those goods probably go abroad as well (Bukowski $\mathrm{i}$ in., 2012).

The dysfunctional mechanism of management of European funds is strengthened by the conservative attitude of public administration, which, when assessing projects for subsidizing, mostly chooses ones that are not very ambitious and not very risky. Breakthrough innovative ides do not fit this category. The analysis of the structure of resources allocated as part of the Innovative Economy operational programme shows that large enterprises receive the larger part of the resources. The smaller the company, the harder it is to obtain financing, because in the application assessment procedure, the highest weight is attributed to criteria that are not connected with the projects' quality or innovativeness but ones that minimize the risk of failure. In effect, the majority of resources is spent as non-refundable aid for not very innovative capital investments of large enterprises, e.g., the modernization of production lines. Thus, public aid goes to safe investment projects of large enterprises, generating considerable effects of idle loss, i.e. subsidizing projects that would be executed even without the aid. The lack of innovation generation potential causes a phenomenon of investing bubble, i.e. the mechanism of too quick increase of innovation expenditure (Freeman, Reenen, 2009). Suddenly received financial resources cannot be effectively used by officials and entrepreneurs who do not have relevant experience or skills. Creating science and technology parks in Podlasie Province is an example of the "investing bubble" phenomenon. Over less than twenty years, 3 such institutions have been established within an approx. $100 \mathrm{~km}$ area: in Białystok, Łomża, and Suwałki. Yet, activity connected with generating innovations is only carried out in the Białystok Park. In Suwałki, such activity is negligible; in Łomża, it does not exist at all.

So in more than ten years, the authorities of many provinces have seen that the construction of a science and technology park and equipping it with cutting edge laboratories is no guarantee of generating innovation. Often, instead of the expected economic acceleration, RSI institutions become a generator of costs for local authorities. True, over the latest few months, some changes to Polish innovation policy have emerged, made in the spirit of assumptions of the Innovation Union project. In new contests organized by the Ministry of Science and Higher Education, EU resources are directly assigned to private enterprises. Local governmental bureaucracy is skipped, but on the other hand, the science sector is marginalized. Contest beneficiaries are motivated to carry out their own R\&D activity. Taking into account the fact that in Poland these are mainly branches of international concerns, I have serious doubts about the reasonableness of this change. It is going to consolidate the imitation character of Polish innovation, manifested in the economic capital goes to economic capital mechanism. 


\section{CONCLUSIONS}

Since in Polish politics innovation is a category borrowed from a European strategy, it includes the same defects and obvious faults rooted in the discourse of international organizations. The model of innovative economy was developed as a remedy for the declining type of economy based on the production formula. Innovativeness was to be a way to retain industry in Europe, and innovations were to counterbalance the trap of medium income, characteristic of medium-developed countries. Still, it needs to be stressed that Poland has not yet reached the level when the risk of getting stuck in the trap of medium income may be real (Bukowski i in., 2012). An attempt to build an innovation system in an economy that has just begun to improve its production capacity and is at the stage of transformation from under- to medium-developed is an extremely difficult task, if not doomed to failure. Even nowadays, when the first decade of implementation of innovative policy is coming to its end, Polish economy has low production potential, and economic development is actuated by small and medium-sized enterprises, mostly from the sector of services. However, innovative activity of those companies is one of the poorest elements of Polish system of innovation. The reason for this is the assumptions of EU policy, in which it was too optimistically assumed in advance that actors equipped with certain instruments would use them according to the plan prepared top-down and realized in the form of regional strategies of innovation.

In accordance with the neo-liberal concept of New Public Management, standards and recommendations drawn up by the EU and the OECD are part of the global network of governance and more and more determine the functioning of national institutions. This process follows the mechanism of imitative modernization strategy, i.e., borrowing foreign solutions and transferring them e.g. to Polish public sector organizations. Yet, P. Hensel questions the rationality of the imitative strategy: "The effects of organizational innovations in the public sector are usually hard to measure, so the popularity of a certain management technique or reform school results from ideological reasons and non-empirical belief that the plans are rational rather than from evidence of actual effectiveness of the solution. The problem goes unnoticed thanks to the process of generalization: the more often we use categories and labels connected with specific reforms (e.g., New Public Management, public-private partnership), the less we can perceive the specificity and local determinants of those reforms" (Hensel, 2015). Thus, we should concentrate on imitating objectives and values, not the methods of achieving them.

I have the impression that in Poland the creation of innovative economy is extremely risky. If the innovativeness of a country depends on economic factors, its potential will not change through the application of science-oriented policy. The idea of establishing collaboration between economic and scientific entities concentrated on an area cannot exist in poorly industrialized regions, where companies are significantly dispersed not only in terms of geographic location but also the direction of activity. To conclude, in Poland economic determinants are a brake for the speeding bureaucratic machinery of European innovation systems. Cultural factors, connected among others with the conservative attitude of public administration or entrepreneurs, as well as barely developing scientific potential, are elements of secondary importance, unnecessarily subject to excessive EU regulations. I can see no justification for the process of transformation of the system of science in Poland to comply with the rigor of innovation system, which in our country is still a matter of future. We still do not know how much the commercialization of knowledge and universities really 
stimulates the country's economic growth. The experience of developed EU countries shows, however, that this effect is much lower than expected (Nelson, Rosenberg, 2001).

\section{REFERENCES}

Bukowski, M., Szpor, A., Śniegocki, A. (2012). Potencjat i bariery polskiej innowacyjności. Warszawa: Instytut Badań Strukturalnych.

Conference of Rectors of Polish Universities. (2013). Finansowa zapaść. „Forum Akademickie” Nr 9.

Czerwińska, E. (2004). Strategia Lizbońska. Warszawa: Biuro Studiów i Ekspertyz. Kancelaria Sejmu.

Dutta, S., Lanvin, B., Wunsch-Vincent, S. (2015). The Global Innovation Index 2015: Effective Innovation Policies for Development. Ithaca, NY, USA, Fontainebleau, France and Geneva, Switzerland: Cornell University, INSEAD, World Intellectual Property Organisation.

European Commission. (2010). Europe 2020. A European Strategy for Smart, Sustainable and Inclusive Growth. Brussels: European Commission.

European Commission. (2012). Pro Inno Europe, Innovation Union Scoreboard 2011. The Innovation Union's Performance Scoreboard for Research and Innovation. Brussels: European Commission.

European Commission. (2015). Innovation Union Scoreboard 2015. Brussels: European Commission.

Freeman, R., Reenen, J.V. (2009). What if Congress Doubled R\&D Spending on the Physical Sciences? [w:] Lerner, J., Stern, S., red., Innovation Policy and the Economy. Chicago: University of Chicago.

Hensel, P. (2015). Naśladowcza strategia modernizacji - co teoria organizacji mówi o imitacji reform?. "Studia Socjologiczne" Nr 4.

Lundvall, B-Å., Borras, S. (1997). The Globalising Learning Economy. Implications for Innovation Policy. Brussels: European Commission.

Malerba, F. (2004). Sectoral Systems of Innovation and Production. "Research Policy" $\mathrm{Nr} 31$.

Narula, R., Guimon, J. (2010). The R\&D Activity of Multinational Enterprises in Peripheral Economies Evidence From the EU New Member States. Maastricht: Maastricht Economics and Social Research and Training Centre on Innovation and Technology.

OECD, EUROSTAT. (2005). The Measurement of Scientific and Technological Activities: Proposed Guidelines for Collecting and Interpreting Technological Innovation Data (Oslo Manual). Paris: OECD.

OECD. (2013). OECD Science, Technology and Industry Outlook: Comparative Performance of National Science and Innovation Systems. Paris: OECD Science, Technology and R\&D Statistics.

OECD. (2014). OECD Science, Technology and Industry Outlook 2014. Paris: OECD Science, Technology and R\&D Statistics.

OECD. (2014). Science, Technology and Industry Outlook: Comparative Performances of National Science and Innovation Systems Paris: OECD Science, Technology and R\&D Statistics.

Okoń-Horodyńska, E. (2012). Małopolska Regionalna Strategia Innowacji: kolejne wyciskanie „brukselki” czy szansa na ambitna politykę rozwoju? „Małopolskie Studia Regionalne” Nr 1-2/24-25. 
Okoń-Horodyńska, E. (2014). Polityka innowacji w UE: przerost formy nad treścia? [Access: 11.03.2017]. Referat wygłoszony na IX Kongres Ekonomistów Polskich. Access on the internet: http://www.pte.pl/kongres/referaty/Okoń-Horodyńska\%20Ewa/Okoń-Horodyńska\%20Ewa\%20-\%20POLITYKA\%20INNOWACJI\%20W\%20UE\%20-\%20PRZEROST\%20FORMY\%20NAD\%20TREŚCIĄ.pdf

PARP. (2010). Badania rynku ustug-transfer technologii. Warszawa: PARP.

PARP. (2013). Regionalne Systemy Innowacji w Polsce. Raport z badań. Warszawa: PARP.

Solow, R.M. (1957). Technical Change and the Aggregate Production Function. "Review of Economics and Statistics” Nr 39.

Waresa, M.A. (2015). Narodowy system innowacji $w$ Polsce $i$ jego zmiany $w$ latach 2007-2014 [w:] Waresa, M.A., red. Raport o konkurencyjności 2015. Innowacje a pozycja konkurencyjna polskiej gospodarki w latach 2007-2014. Warszawa: Szkoła Główna Handlowa.

DOI: $10.7862 /$ rz.2019.hss.4

The text was submitted to the editorial office: October 2017.

The text was accepted for publication: March 2019. 